\title{
A degree of recognition across policing: embedding a degree apprenticeship encompassing work-based research
}

\author{
Ian Pepper \\ University of Sunderland, Sunderland, UK and \\ Faculty of Life Sciences and Education, University of South Wales, Pontypridd, UK \\ Ian Brown \\ Superintendent, Metropolitan Police Service, London, UK, and \\ Paul Stubbs \\ Chief Inspector, Metropolitan Police Service, London, UK
}

\begin{abstract}
Purpose - As the police service across England and Wales moves towards degree-level study for new recruits as a component of recognising the profession of policing, this paper describes and discusses the introduction of the Police Constable Degree Apprenticeship (PCDA) and the core skills of evidence-based policing (EBP) as an educational theme for solving work-based problems.

Design/methodology/approach - Authored by both policing practitioners and researchers, this paper refers to key literature whilst exploring the implementation of the PCDA as a component of a Policing Education Qualifications Framework (PEQF). It highlights some of the challenges faced with its implementation along with the benefits of the adopting this degree-level education and work-based programme where EBP is embedded in to both study and professional practice.

Findings - There are significant benefits to the police service of adopting the PCDA as one of the entry routes for new police constables and embracing the educational development and professional application of EBP. However, this does not come without a number of challenges for the service and the professional body for policing.

Originality/value - This paper, co-authored by both policing practitioners and researchers, provides a contemporary view on the introduction of the PCDA as an initial entry route for new police constables and the embedding of EBP within both their learning and professional practice. As the first graduates complete their studies, the paper discusses the opportunities the adoption presents and the challenges it faces both locally and nationally.
\end{abstract}

Keywords Higher education, Degree apprenticeship, Evidence-based policing, Police constable, Work-based Paper type Viewpoint

\section{Introduction}

The recognition of policing as a profession has been debated for many years (Rojek et al., 2012; Brown et al., 2018) and has long been an ambition for the police service. Green and Gates (2014) discuss a number of core components of a profession, amongst which are the development of an organised body of knowledge and nationally recognised professional qualifications. From the summer of 2022, the professionally focused Police Constable Degree Apprenticeship (PCDA) will be one of only two initial entry routes for those recruited and

(C) Ian Pepper, Ian Brown and Paul Stubbs. Published in Journal of Work-Applied Management. Published by Emerald Publishing Limited. This article is published under the Creative Commons Attribution (CCBY 4.0) licence. Anyone may reproduce, distribute, translate and create derivative works of this article (for both commercial and non-commercial purposes), subject to full attribution to the original publication and authors. The full terms of this licence may be seen at http://creativecommons. org/licences/by/4.0/legalcode

A degree of recognition across policing

Received 22 December 2020 Revised 23 April 2021 15 June 2021

Accepted 26 June 2021

\section{Accepted 26 June 2021}


JWAM

14,1

employed as new police constable for the police service across England and Wales, with an additional Pre-join degree entry route for those aspiring to join the police service but not yet employed as constables. During 2020/2021 the 43 territorial police forces across England and Wales recruited over 9,200 new police constables (Gov.UK, 2021a), with the Home Office (2019) providing funding to recruit an additional 20,000 constables by 2023. As of March 2021 there were slightly over 1,900 new student officers enrolled on PCDA's (Gov.UK, 2021b), this will increase as more PCDA partnerships between police forces and higher education providers are licensed by the College of Policing and begin their co-delivery.

Fergusson (2019) details a range of individual benefits for studying such programmes of work-based learning including increased confidence, motivation and competence. Individual benefits such as these can easily be transposed to those studying the PCDA, which is a step towards the recognition of the profession of policing and embedding of apprentice graduatelevel skills across the service. Higher education providers and employers, in this case the police forces, must collaborate effectively in the design and delivery of their apprenticeships. The blend of these professionally focused programmes of both academic structure and workbased practice being important (Lester et al., 2016).

Such a blended approach is a key component of the PCDA and given the unique characteristics of each police force, it allows the programme of study to be tailored to meet community, national and apprentice needs. It is of note, however, that a common thread throughout the PCDA is the development of knowledge, skills and the application of evidence-based policing (EBP) to professional practice; however, this does not come without hurdles.

This paper seeks to discuss the broad themes of the PCDA and comment on the adoption of EBP as a key component of the programme in order to enhance professional policing practice. The paper will not draw on any data beyond that referred to within the discussion.

During the summer of 2021 several hundred new police constables studying the PCDA are the first to complete their learning and research projects, be awarded their degrees and successfully graduate. So now is the time to reflect upon the adoption of the PCDA and its core thread of EBP, the benefits it can bring to the service and the challenges it presents.

\section{Discussion}

Degree Apprenticeships were formally launched by the UK Government in 2015 (Department for Business, Innovation and Skills/Prime Minister's Office, 2015), with funding for the learning being supported by an apprenticeship levy applied across employers (Gov.UK, 2016). The aim of Degree Apprenticeships are to bring together groups of employers and higher/vocational education providers to co-design programmes which allow apprentices to study for and achieve a degree, whilst learners develop higher level professional workplace skills which meet the requirements of both employers and the wider labour market (Department for Business, Innovation and Skills/Prime Minister's Office, 2015).

The well-established higher vocational education in Switzerland was also developed to enable the acquisition by learners of the higher level skills required by employers (Nägele et al., 2018), with programmes being delivered through Universities of Applied Sciences who are governed by Federal Law, the steering groups of which have strong links with employers (Graf, 2016). In Germany, training integrated dual study university programmes are growing in demand, as they blend academic and professional skills development whilst leading to the award of both a bachelor's degree and vocational certification (Mordhorst and Gössling, 2020). Graf (2016) describes how the profile of the German dual study programmes are negotiated locally and are flexible enough to ensure the needs of specific employers within the learning partnerships are met. In the UK, the importance of engaging nationally with employers is reflected in the development of apprenticeship standards for specific 
occupations by Institute for Apprenticeships and Technical Education endorsed National Trailblazer Groups, which are established to represent a cross section of possible employers.

In 2016, the professional body for policing, The College of Policing, proposed the establishment of a standardised Policing Education Qualifications Framework (PEQF) with a range of initial entry routes, including the PCDA, all of which were to encompass degree-level study (Pepper and McGrath, 2019). Wood (2020) describes how the establishment of such a standardised educational framework for policing is an important step to ensure police constable are equipped with the best knowledge, understanding and workplace skills. Shortly afterwards, a National Trailblazer Group initially designed (and continues to review), the PCDA as an initial entry route for new police recruits who do not already hold an honours degree.

The PCDA is studied over three years whilst employed full-time as a police constable with successful completion of both academic study and application in practice leading to the award of a BSc or BA (Hons) in Professional Policing Practice and confirmation in post as a police constable. The apprenticeship is fully funded for the individuals, with the learners employed by a police force from their first day, being paid and attested as police constables. The programme of study is work-based and taught through partnerships established between higher education providers and police forces. Mulkeen et al. (2019) discuss the importance of collaborations co-creating such programmes of study. It is a requirement that the apprenticeship programme is co-created, ensuring alignment of the learning to the standardised National Policing Curriculum (NPC) whilst meeting the needs of local employers. Following programme design, the co-created programme is then quality assured and licenced by the College of Policing. Such partnership working between the educational providers, employers and professional bodies, is essential for the effective ongoing delivery of Degree Apprenticeships (Lester, 2020).

The primary aim of the apprenticeship is to facilitate a learner's development as a new police constable able to demonstrate professional competence in the workplace (Quality Assurance Agency for Higher Education (QAA), 2019). The learning is supported by an embedded higher educational qualification, with graduates being able to demonstrate skills such as taking responsibility and decision making (ibid.). The QAA (2018) continue to describe how this can be achieved throughout an apprentices learning journey by providing the opportunity for learners to apply and incorporate both professional and subject specific knowledge, along with the skills and expected behaviours, into everyday workplace professional practice. Importantly, tripartite meetings between the learner, university academic and experienced police frontline trainer/tutor compliment and reinforce the apprentices learning and development. Such co-development and blurring of the more traditional lines of learning often split between employers and higher education providers was identified as important by Mulkeen et al. (2019).

This highlights the importance of valuing the workplace as an integral location for learning to take place (Lester et al., 2016) and for the generation of knowledge (QAA, 2019). Learners are abstracted from their regular policing role for a minimum of $20 \%$ of their time for "off the job" learning, which Lester (2020) suggests may range from attending the university to e-learning or independent study. Although the College of Policing (2020) reports agreements between some forces and their higher education providers in the region of $30 \%$ abstraction.

The other route of entry as a newly employed police constable is a shorter two year College of Policing licenced programme of police focused study for existing degree holders of any academic discipline, this leads to the award of a Graduate Diploma in Professional Policing Practice. In addition to the PCDA and Graduate Diploma, there is a self-funded degree for aspiring police constables which is delivered purely by higher education providers. This selffunded knowledge-based Pre-join degree in Professional Policing is aligned to the NPC, with each higher education provider delivering the programme also requiring initial quality
A degree of recognition across policing 
JWAM

14,1

assurance and then licencing by the College of Policing. This suite of transformational entry routes for new and aspiring police constables provides an opportunity to further evolve the recognition of the service as a profession.

The College of Policing (2020) report how by the autumn of 2020, 29 of the 43 territorial police forces across England and Wales have gone live with the delivery of the PCDA with their partner higher education institutions (other forces have plans to go live throughout 2021). The partnerships range from a single force of 1,200 police officers of all ranks working with their local university to deliver the PCDA across one or two cohorts per year with small numbers of new police constable recruits, to the largest police force in the country with over 31,000 police officers, with a learning partnership managed between a consortium of four universities for the delivery of the PCDA (Babcock, 2020), with multiple cohorts of new police constables starting at multiple times throughout the year. Leek (2020) suggests how the collaborative development of PCDA's is positively impacting on the cultural transition of police forces towards becoming learning organisations.

Subjects taught within the programme are many and varied including response, community, counter terrorism, digital and roads policing, information and intelligence, conducting investigations, public protection, EBP, research methods, problem solving, etc. all complimented with ongoing reflective practice, an aspect of such programmes which is imperative to further engender a learning workforce (Helyer, 2015).

The various elements of academic learning are assessed by means of the more traditional assignments, reflections, presentations, exams, short answer questions, etc. The practical workplace skills are assessed through practical application, witness testimony, reflection and professional discussions leading first to independent patrol status (IPS) then full operational competence (FOC). Finally, the raft of assessment methods is completed with an integrated end point assessment (EPA) demonstrating occupational competence (Institute for Apprenticeships and Technical Education, 2019). Included within this final stage of assessment is the requirement for the apprentice to successfully complete a 10,000 word evidence-based research project, during which the constable selects and applies the most appropriate research methodologies for the design, delivery and critical analysis of a policing problem.

The introduction of the PCDA is a significant opportunity for the police service to work towards the full integration of EBP in routine policing practice, as a result aligning the profession of policing with other professional occupations (Pepper et al., 2020).

Rojek et al. (2015) detail how research partnerships can assist in improving a police forces ability to identify problems and inform responses by providing specific knowledge, experience and analytical skills to conduct empirical studies. Brown et al. (2018) discuss the importance of embedding EBP within the new educational routes for police constables. Lester et al. (2016) suggest a common feature of work-based degrees is problem-solving projects focused on resolving a work-based issue. Whilst the knowledge and skills of a constable to take individual responsibility for analysing, interpreting, applying, evaluating and sharing evidence of what works in practice is highlighted by the Institute for Apprenticeships and Technical Education (2018). The introduction of the PEQF initial entry routes go hand-inhand with the broader adoption of EBP by the service, with its application of knowledge to everyday policing (Wood, 2020).

As such the PCDA contains as a core theme the requirement for learners to understand EBP and apply its concepts in undergraduate problem-solving and research, with opportunities to learn such skills threaded throughout their studies. The study areas include learning a range of definitions of EBP, understanding values of research evidence types, identifying sources of evidence, methodological approaches to research, the use of EBP in the workplace and importantly its application in professional practice. 
The opportunities to the service of adopting EBP through the utilisation of a range of methodological approaches, moving beyond the original ideas of high quality and rigorous experimental design proposed by Sherman (1998), have often been discussed (Brown et al., 2018; Boulton et al., 2020). This isn't to ignore the need for research rigour, but rather embrace the many and varied approaches available to the new constables within the limitations imposed by their studies. In their definition of EBP, The College of Policing (2017) describe the need to use the best available evidence to inform decisions and practice.

Acknowledging that the PCDA is studied at an undergraduate level, an opportunity now exists, supported by experienced academic researchers, to develop amongst new police constables the skills to best utilise a range of methodological approaches to research and address specific, real-time problems faced by policing which can be implemented in to professional practice. Developing such an in depth understanding of the concepts of EBP, along with its application through a problem-based research project, provides an opportunity for higher education providers to share their significant research expertise with policing partners and for individual police forces to complete a volume of focused, university ethically approved and methodologically sound research on specific topics of interest to the service.

Bolton-King et al. (2020) highlight how annually there are already significant numbers of undergraduate criminal justice research projects completed, however, there are often difficulties linking and then translating academic research in to professional practice (Rojek et al., 2015; Brown et al., 2020). The need to make effective use of Degree Apprenticeship workbased projects was also identified by Lester (2020).

Given the large volume of research projects that will be completed by PCDA students, not only individual forces but the police service as whole, has an opportunity to collate and utilise the multiplicity of research findings. However, as Brown et al. (2020) highlight, many professions are using evidence-based approaches to inform professional practice rather than define and limit practice. The importance of involving police practitioners in the research process is identified by Hunter et al. (2019), with the benefits to the police from using the findings of such research projects highlighted by Brown et al. (2018), where the rapid growth in snatch crimes using mopeds across London were examined. The growth of such crimes had led to multi-institutional approaches to educating the public across London regarding the risks of becoming a victim and the police evolving a range of approaches to apprehend the offenders. Approaches included the development of specific teams and tactics, including spraying offenders with marker spray, deflating tyres with stingers and knocking suspects off of their mopeds in tactical police contacts. Such approaches significantly decreased the number of occurrences of moped enabled offences in some areas, although of course it can be argued that some of the crime has been displaced. However, the Metropolitan Police Service (2019) reported an overall reduction, during the year 2018-2019, of just over $52 \%$ of these types of crimes on the previous year.

Fergusson (2019) suggests that work-based problems are usually multi-faceted, dynamic and constantly changing, as a result when the outcomes are shared more widely, the problem has evolved and moved on. As an example, this could well be the case in moped-enabled snatch crimes. Booth (2019) describes how following the increased use of police tactical contacts with mopeds to stop offenders, those committing such snatch crimes in one area of London, switched to using bicycles rather than mopeds, as they can sneak up behind a possible victim who is totally unaware of the presence of a bicycle until it was too late. Limited localised data available up until the nations lockdown in March 2020 may once again suggest an upward trend in two wheeled enabled "snatch crimes". Goldstein's (1990) original concept of problem-oriented policing (POP) is still viewed as an effective strategy to tackle crime (Hinkle et al., 2020). This problem-solving approach to develop targeted interventions has evolved to include other problem-solving models to identify and tackle crime and disorder, such as SARA (defined as scanning, analysis, response and assessment). A POP approach to
A degree of recognition across policing 
JWAM

14,1

tackling snatch crimes using two wheeled modes of transport can easily be linked to an EBP approach to solving the problems by utilising current research to pro-actively evolve interventions, with the findings from such interventions being shared and then re-evaluated. However, Scott (2017) highlights differences between both approaches, discussing how POP is focused on achieving policing objectives as opposed to EBP which is focussed towards developing robust research to inform professional practice.

The research projects of new police constables studying the PCDA could do much to develop, in a timely manner, the evidence base of how to best respond to these crime types. If effectively co-ordinated, ethically approved and supported with academic researcher expertise, the police practitioner-researchers could focus small-scale manageable and methodologically sound research projects on numerous aspects of such crimes. These projects could range from their ethically approved access for quantitative analysis of existing police statistics and comparison of cross force border crimes to the qualitative exploration of existing police officer experiences and impact on victims, all of which could add up to a broad and in-depth picture at little direct cost to the service.

The benefits of PCDA students implementing EBP in an attempt to resolve such upcoming issues have many strengths. At a strategic level for policing it provides the opportunity to enhance and grow a national body of quality and ethically approved evidence to inform and develop professional policing practice of what does (and does not) work, as a result demonstrating legitimacy in the way the police service operates. However, Bolton-King et al. (2020) discuss a hurdle to address in that practitioner-researcher is often not written up, let alone shared widely, this is a missed opportunity. Considering this in a national context, if the opportunity to share the outcomes of such research is not effectively embraced, it could also pose a risk to ability of the College of Policing, as the professional body, to share the evidence-based good professional practice across the service.

At an operational level, the introduction and application of EBP should enable new police constables to better understand the language of academic research and link this to the needs of practitioners (Rojek et al., 2015), as a result impacting on the way they work. However, the methodologies adopted for such research should continue to be rigorous but not limited to the traditional experimental approaches (Lumsden, 2017; Brown et al., 2018). The intention being that those studying the PCDA will better understand the range of tools which can be applied to solve both short- and long-term contemporary policing problems. The adoption of EBP can also evolve the way the police operates by reflecting upon what the research tells the service. It enables police constables to use their new academic and research skills to assist their own professional practice throughout their careers, complementing the large body of "experience" and skills of the "craft" which already exists amongst the 131,000 police officers currently within the service (Home Office, 2020).

The embedding of EBP within this new entry route for police constables, and within the wider service as their careers develop, brings many opportunities for research in a unique environment where police practitioners already have access. Whilst studying the PCDA, they are able to conduct subject-specific research with the support of university expertise and the appropriate ethical approvals. As part of this, the learners and researchers have a unique opportunity for community engagement, as the community can inform their research, whilst the outcomes can have an almost immediate and directly positive impact on the lives of the community, as a result assisting in building a wider confidence in the service. Such opportunities for research impact are discussed by Wall et al. (2017), who describes how these work-based research outcomes also offer great opportunities for higher education institutions to demonstrate real-world impact for their own national measures of research success. In the first instance these outcomes will be at undergraduate level, but with tripartite engagement and support from the PCDA graduates as professional practitioner-researchers, the police service and higher education providers, the opportunities for research growth and impact abound. 
Of course there are challenges to the implementation of the skills of conducting EBP in to professional practice. The research projects within the PCDA at undergraduate level are relatively small at 10,000 words length, governed by short timescales and focussed on achieving an academic award. Those studying need to be cognisant of the potential for researcher bias and the possibility for the influence they may have on the research outcomes due to their perceived position of power within the community. Lester et al. (2016) also discuss the need to be cognisant of potential ethical issues arising from research conducted by those embedded in the workplace.

There is no central repository for evidence collected and outcomes generated by the research projects conducted in each police force, meaning opportunities to share and build upon earlier academic research can easily be missed. There is also limited co-ordination between higher education institutions of the large numbers of policing students involved and in many cases there is limited co-ordination between territorial police forces. This could mean that the same often topical research may be unknowingly duplicated by different new constables (Hunter et al., 2019), as a result limiting the opportunities to move forward with the knowledge base. The implementation of research projects as part of the PCDA raises capacity challenges for police training teams, academics and administrators required for large numbers of learners completing EBP and/or problem-based research projects across multiple cohorts throughout the year. All of learners will require support and guidance from the research inception, ethical and work-based approval, development and conduct, through to assessing and processing of academic awards through to graduation. There may also be challenges of maintaining the confidence of the broader public if police constables appear to be fewer in number on the streets at a given periods each year when the research projects are being completed and written up.

Although PCDA graduates will be equipped to use their academic and problem-solving skills to assist their professional practices throughout their careers, there is no current requirement for ongoing continuing professional development (CPD) relating to EBP for these new constables. So once the academic research is complete for their PCDA and they have graduated, it could be possible to opt to have a career with no further academic skills development. However, following graduation, learners will have developed the ability to manage their own learning, use scholarly material and identify their need for further training and development (QAA, 2014). As a result, hopefully a number of the PCDA graduates will be inspired to continue in higher education and move on in their studies engaging in postgraduate research and associated postgraduate awards.

It must not be forgotten that there is also the huge cultural challenge of internal engagement by those currently serving within policing to remain motivated given the value the police service currently places on the informal validation of "experience" and "craft" as it now shifts towards the external validation by academic processes and degree-level recognition for new recruits to the service. This engrained practice of those already within policing imparting their professional knowledge, skills and experiences via storytelling is highly valued across the police culture (McNulty, 1994), yet this contradicts the educational approach adopted through the PCDA which advocates the need for a sound foundation of evidence for solving problems and making decisions, aligning to the approach of other professions. As Wall et al. (2017) suggest, the impact of the practitioner-researchers presence extends well beyond their initial research, resonating within and influencing the workplace over time.

\section{Conclusion}

As a result of implementing the PCDA as an initial entry route within the PEQF for new police constables, there is the opportunity to transform the way policing works for the benefit of both the community and the service. The move from internally driven "experience" or "craft" 
JWAM

14,1

of policing towards a standardised higher education accredited, recognised and validated programme of study presents opportunity as well as challenge. It is hoped the new initial entry routes will embed the concept of the police in society as a profession, one which makes good decisions informed by the best available research (Hunter et al., 2019).

A graduate qualification achieved through studying the PCDA allows the public, the criminal justice system and other employers to recognise, compare and understand the level of professional competence and expertise of police constables. Higher education, which also benefits significantly from the introduction of the PCDA, plays a key role in the development of the graduate-level apprentice skills. Embedding core skills such as taking responsibility, problem solving, decision making and evidence-based research will become increasingly important in the contemporary policing environment. These skills will be key in equipping officers with the ability to use problem-solving techniques to bring about long-term solutions to policing issues locally, regionally and nationally. The importance of involving police practitioners in the development of the knowledge base for policing along with the adoption and utilisation of research skills by new constables are essential in ensuring EBP is successfully embedded and utilised across the service (Green and Gates, 2014). The adoption of higher education also assists in the development of additional skills including the willingness to embrace alternative perspectives, moral and ethical reasoning along with empathy. This supports the findings of Mazerolle et al. (2013) of the positive impact on the public and their levels of cooperation if they feel actions of the police are fair, neutral and legitimate. Such core graduate skills may also prove useful when those working in policing decide to leave the service, as they are transferrable to other career opportunities.

The research carried out by officers as part of their degree programmes will contribute to the body of evidence showing what does, and does not, work in policing, which provides a resource for those looking at innovative solutions to long-terms issues. Although not without challenges to be addressed, not least of which is the significant cultural change that should take place over time, the adoption of the PCDA and embedding the skills of EBP is a huge opportunity for those within policing to use academic knowledge, understanding and skills to solve everyday problems for the benefits of the individual, police service and the community whilst moving towards the recognition of the profession of policing.

\section{References}

Babcock (2020), Babcock Awarded Contract to Provide Services to London's Police: 26 November 2019, available at: https://www.babcockinternational.com/news/babcock-awarded-contract-toprovide-services-to-londons-police/ (accessed 18 December 2020).

Bolton-King, R., Kara, H., Cassella, J., Rankin, B., Morgan, R., Burke, S., Fripp, D. and Kaye, J. (2020), "Increasing the accessibility and impact of justice-related student and practitioner", Forensic Science International: Synergy, Vol. 2, pp. 60-71, doi: 10.1016/j.fsisyn.2019.09.009.

Booth, S. (2019), "Phone snatch thieves using 'stealth' tactics on pedal bikes", Camden New Journal: The Independent London Newspaper, 09 May 2019.

Boulton, L., Phythian, R., Kirby, S. and Dawson, I. (2020). "Taking an evidence-based approach to evidence-based policing research", Policing: A Journal of Policy and Practice, paaa057. doi: 10. 1093/police/paaa057.

Brown, J., Belur, J., Tompson, L., McDowall, A., Hunter, G. and May, T. (2018), "Extending the remit of evidence-based Policing", International Journal of Police Science and Management, Vol. 20 No. 1, pp. 38-51.

Brown, J., McDowall, A., Gamblin, D. and Fenn, L. (2020), "Assessing transmission and translation of learning about evidence based policing by graduate trainee police officers", Policing, Vol. 14 No. 1, pp. 119-134. 
College of Policing (2017), "What is evidence-based policing?", available at: https://whatworks.college. police.uk/About/Pages/What-is-EBP.aspx (accessed 9 December 2020).

College of Policing (2020), Policing Education Qualifications Framework Initial Entry Routes. Learning to Date: Development and Implementation, 2016 to 2019, College of Policing, Ryton.

Department for Business, Innovation and Skills/Prime Minister's Office (2015), Press Release: Government Rolls-Out Flagship Degree Apprenticeships, available at: https://www.gov.uk/ government/news/government-rolls-out-flagship-degree-apprenticeships (accessed 13 June 2021).

Fergusson, L. (2019), “The nature of work-related problems: messy, co-produced and wicked”, Journal of Work-Applied Management, Vol. 11 No. 2, pp. 106-120, doi: 10.1108/JWAM-08-2019-0024.

Goldstein, H. (1990), Problem Orientated Policing, McGraw-Hill, New York.

Gov.UK (2016), Policy Paper: Apprenticeship Levy, available at: https:/www.gov.uk/government/ publications/apprenticeship-levy/apprenticeship-levy (accessed 5 April 2021).

Gov. UK (2021a), Police Officer Uplift, England and Wales, Quarterly Update to 31 March 2021, available at: https://www.gov.uk/government/statistics/police-officer-uplift-quarterly-update-tomarch-2021/police-officer-uplift-england-and-wales-quarterly-update-to-31-march-2021 (accessed 15 June 2021).

Gov.UK (2021b), Academic Year 2020/21: Apprenticeships and Traineeships, available at: https:// explore-education-statistics.service.gov.uk/find-statistics/apprenticeships-and-traineeships (accessed 13 June 2021).

Graf, L. (2016), "The rise of work-based academic education in Austria, Germany and Switzerland", Journal of Vocational Education and Training, Vol. 68 No. 1, pp. 1-16, doi: 10.1080/13636820. 2015.1107749.

Green, T. and Gates, A. (2014), "Understanding the process of professionalisation in the police organisation”, Police Journal: Theory, Practice and Principles, Vol. 87, pp. 75-91, doi: 10.1350/ pojo.2014.87.1.662.

Helyer, R. (2015), "Learning through reflection: the critical role of reflection in work-based learning (WBL)", Journal of Work-Applied Management, Vol. 7 No. 1, pp. 15-27.

Hinkle, J., Weisburd, D., Telep, C. and Petersen, K. (2020), "Problem-oriented policing for reducing crime and disorder: an updated systematic review and meta-analysis", Campbell Systematic Reviews, Vol. 16 No. 2, pp. 1-86, doi: 10.1002/cl2.1089.

Home Office (2019), National Campaign to Recruit 20,000 Police Officers Launches Today, available at: https:/www.gov.uk/government/news/national-campaign-to-recruit-20000-police-officerslaunches today\#: :text $=\mathrm{A} \% 20$ national $\% 20$ campaign $\% 20$ to $\% 20$ recruit,over $\% 20$ the $\% 20$ next \%203\%20years (accessed 18 December 2020).

Home Office (2020), Police Workforce, England and Wales, 31 March 2020, available at: https:/assets. publishing.service.gov.uk/government/uploads/system/uploads/attachment_data/file/905169/ police-workforce-mar20-hosb2020.pdf (accessed 21 December 2020).

Hunter, G., May, T. and Hough, M. (2019), “Are the police embracing evidence-informed practice?”, A View from England and Wales, Policing and Society, Vol. 29 No. 3, pp. 251-265, doi: 10.1080/ 10439463.2018.1557180.

Institute for Apprenticeships and Technical Education (2018), Police Constable Degree, available at: https://www.instituteforapprenticeships.org/apprenticeship-standards/police-constable(degree)-v1-0 (accessed 13 December 2020).

Institute for Apprenticeships and Technical Education (2019), Developing an End-Point Assessment Plan, available at: https:/www.instituteforapprenticeships.org/developing-new-apprenticeships/ developing-an-end-point-assessment-plan/ (accessed 10 April 2021).

Leek, A. (2020), "Police forces as learning organisations: learning through apprenticeships", Higher Education, Skills and Work-Based Learning, Vol. 10 No. 5, pp. 741-750, doi: 10.1108/HESWBL05-2020-0104. 
JWAM

14,1

Lester, S. (2020), "Creating conditions for sustainable degree apprenticeships in England", Higher Education, Skills and Work-Based Learning, Vol. 10 No. 5, pp. 701-714, doi: 10.1108/HESWBL04-2020-0062.

Lester, S., Bravenboer, D. and Webb, N. (2016), Work Integrated Degrees: Context, Engagement, Practice and Quality, available at: http://devmts.org.uk/wid.pdf (accessed 3 April 2021).

Lumsden, K. (2017), "Police officer and civilian staff receptivity to research and evidence-based policing in the UK: providing a contextual understanding through qualitative interviews", Policing: A Journal of Policy and Practice, Vol. 11 No. 2, pp. 157-167, doi: 10.1093/police/ paw036.

Mazerolle, L., Antrobus, E., Bennett, S. and Tyler, T. (2013), "Shaping citizen perceptions of police legitimacy: a randomized field trial of procedural justice", Criminology, Vol. 51 No. 1, pp. 33-63.

McNulty, E. (1994), "Generating common sense knowledge among police officers", Symbolic Interaction, Vol. 17 No. 3, pp. 281-294.

Metropolitan Police Service (2019), Metropolitan Police Service Business Plan Progress Update 201819, Quarter 4 (January to March 2019), available at: https:/www.met.police.uk/SysSiteAssets/ media/downloads/met/about-us/met-business-plan-2018-19-q4-progress-report (accessed 21 December 2020).

Mordhorst, L. and Gössling, B. (2020), "Dual study programmes as a design challenge: identifying areas for improvement as a starting point for interventions", EDeR - Educational Design Research, Vol. 4 No. 1, pp. 1-36, doi: 10.15460/eder.4.1.1482.

Mulkeen, J., Abdou, H., Leigh, J. and Ward, P. (2019), "Degree and Higher Level Apprenticeships: an empirical investigation of stakeholder perceptions of challenges and opportunities", Studies in Higher Education, Vol. 44 No. 2, pp. 33-346, doi: 10.1080/03075079.2017.1365357.

Nägele, C., Neuenschwander, M. and Rodcharoen, P. (2018), "Higher education in Switzerland: predictors of becoming engaged in higher vocational or higher academic education The role of workplace factors", International Journal for Research in Vocational Education and Training, Vol. 5 No. 4, pp. 264-284, doi: 10.13152/IJRVET.5.4.2.

Pepper, I. and McGrath, R. (2019), "Embedding employability within Higher Education for the profession of policing", Higher Education, Skills and Work-Based Learning, Vol. 9 No. 3, pp. 319-328, doi: 10.1108/HESWBL-06-2018-0061.

Pepper, I., Rogers, C. and Martin, H. (2020), "Evidence based policing: a view on its development within the police service", Journal of Work-Applied Management, Vol. 12 No. 1, pp. 91-96, doi: 10. 1108/JWAM-01-2020-0001.

QAA (2014), UK Quality Code for Higher Education. Part A: Setting and Maintaining Academic Standards. Part A, Quality Assurance Agency, Gloucester.

QAA (2018), UK Quality Code for Higher Education - Advice and Guidance: Work-Based Learning, Quality Assurance Agency, Gloucester.

QAA (2019), Characteristics Statement: Higher Education in Apprenticeships, available at: https://www. qaa.ac.uk/docs/qaa/quality-code/characteristics-statement-apprenticeships.pdf (accessed 10 June 2021).

Rojek, J., Alpert, G. and Smith, H. (2012), "The utilization of research by the police”, Police Practice and Research, Vol. 13 No. 4, pp. 1-13, doi: 10.1080/15614263.2012.671599.

Rojek, J., Martin, P. and Alpert, G. (2015), Developing and Maintaining Police-Researcher Partnerships to Facilitate Research Use, Springer, New York.

Scott, M. (2017), “Chapter 3: reconciling problem orientated policing and evidence based policing", in Knutsson, J. and Tompson, L. (Eds), Advances in Evidence-Based Policing, Routledge, London.

Sherman, L. (1998), Evidence-based Policing: Ideas in American Policing, Police Foundation, Washington, DC. 
Wall, T., Bellamy, L., Evans, B. and Hopkins, S. (2017), "Revisiting impact in the context of workplace research: a review and possible directions", Journal of Work-Applied Management, Vol. 9 No. 2, pp. 95-109, doi: 10.1108/JWAM-07-2017-0018.

Wood, D. (2020), "Maintaining professional standards and reflective practice", in Pepper, I. and McGrath, R. (Eds), An Introduction to Professional Policing: Examining the Evidence Base, Routledge, Abingdon.

A degree of recognition across policing

\section{Corresponding author}

Ian Pepper can be contacted at: I.Pepper@sunderland.ac.uk

For instructions on how to order reprints of this article, please visit our website:

www.emeraldgrouppublishing.com/licensing/reprints.htm

Or contact us for further details: permissions@emeraldinsight.com 